logos_i_ethos_2021_1_(56), s. 167-171

DOI: http://dx.doi.org/10.15633/lie.3945

Dominika Janik-Lis

https://orcid.org/0000-0002-5078-956X

Recenzja

\title{
Kazimierz Trzęsicki, Wprowadzenie do metodologii nauk społecznych, Wydawnictwo Uniwersytetu w Białymstoku, Białystok 2018, 241 ss.
}

Metodologia w uprawianiu każdej nauki jest bardzo ważna. Poziom metodologicznego zaawansowania nauki jest jej bezwzględnym walo-

Autorka jest doktorantką na kierunku socjologia na Wydziale Nauk Społecznych na Katolickim Uniwersytecie Lubelskim Jana Pawła II w Lublinie. rem. Nauka, która uzyskała wyso-

ki status metodologiczny, może być pod pewnymi względami uznana przez określoną wspólnotę naukową za naukę wzorcową. Bez kompetencji metodologicznych tak naprawdę trudno jest zdobywać wiedzę intersubiektywnie sprawdzalną i komunikowalną. Dbałość o kulturę logiczną i metodologiczną jest celem metodologów, którzy zainteresowani są podnoszeniem jakości i standardów wiedzy naukowej.

Kazimierz Trzęsicki, polski logik, filozof informatyki, w swojej książce Wprowadzenie do metodologii nauk społecznych przekonuje jak bardzo ważna dla badacza nauk społecznych jest kultura metodologiczna. Publikacja liczy 241 stron, została podzielona na cztery rozdziały, wstęp i zakończenie. Zaopatrzona została w literaturę przedmiotu, która uwzględnia najważniejsze pozycje polskie i zagraniczne.

Książka, choć autor nie pisze tego wprost, została pomyślana jako podręcznik wprowadzający w problematykę metodologii nauk społecznych dla studentów takich kierunków kształcenia, jak socjologa, pedagogika, nauki o polityce czy psychologia. Jednakże po całościowym 
zapoznaniu się z zawartym w niej materiałem należy stwierdzić, że jest ona zaadresowana głównie do studentów i wykładowców socjologii, można by powiedzieć wzorcowej nauki społecznej, w ramach, której prowadzone są badania społeczne. Najważniejsze problemy i spory metodologiczne, jakie miały czy mają miejsce w naukach społecznych, zostały przez autora zobrazowane właśnie na przykładzie tej gałęzi nauki. Publikacja przedstawia podstawowe zagadnienia podejmowane $\mathrm{w}$ obszarze metodologii nauk społecznych i dyskusje toczące się między jej prominentnymi przedstawicielami. Celem autora jest umożliwienie czytelnikowi uzyskania podstawowej orientacji w metodach aplikowanych do badań społecznych.

Rozdział pierwszy podejmuje zagadnienia ogólnometodologiczne. Profesor Trzęsicki omawia w nim takie zagadnienia, jak: co to jest nauka, czym jest metodologia nauk jako nauka o nauce, następnie podejmuje bardzo ciekawe zagadnienie hierarchii i typologii badań naukowych. Informacje zawarte w pierwszym rozdziale mają charakter propedeutyczny, dotyczą rudymentarnych informacji, które potrzebne są każdemu studentowi wchodzącemu na drogę realizacji badań społecznych.

$\mathrm{W}$ rozdziale drugim autor koncentruje się już na problematyce nauk społecznych. Rozdział ten zawiera szereg cennych informacji o charakterze historycznym, przedmiotowym i metaprzedmiotowym. Autor pokazuje, w jaki sposób doszło do wyodrębnienia się nauk społecznych jako osobnej dyscypliny badawczej. Omawia najważniejsze trendy badawcze i przedstawia najistotniejsze dyskusje, które miały miejsce między zwolennikami różnych opcji uprawiania nauk społecznych. W rozdziale tym znajdujemy szereg interesujących analiz i wniosków dotyczących problematyki inżynierii społecznej.

$\mathrm{W}$ rozdziale trzecim autor wprowadza czytelnika w samo sedno metodologii nauk społecznych. Omawia dwie podstawowe strategie metodologiczne, które tak naprawdę ukształtowały oblicze XX-wiecznych nauk społecznych. Pierwsza opcja metodologiczna to indywidualizm, druga zaś to metodologiczny holizm. Autor precyzyjnie omawia szereg zagadnień związanych zarówno z metodologicznym indywidualizmem, jak i holizmem; pokazuje historyczne konteksty kształtowania się tych 
opcji, omawia na przykładach, w jaki sposób te strategie badawcze funkcjonują w obszarze badań społecznych, a także - co najważniejsze - pokazuje, jakie słabe strony ma jedna i druga opcja. Nie poprzestając na wyliczeniu słabych i mocnych stron, sam też proponuje pewne pośrednie stanowisko, które zmierza do wykazania, że indywidualizm i holizm nie muszą się wykluczać, ale mogą ze sobą współistnieć, oferując bardziej przekonujące wyjaśnienia różnych zjawisk społecznych.

Natomiast w rozdziale czwartym prof. Trzęsicki rekonstruuje toczący się od ponad 100 lat na gruncie nauk społecznych spór między naturalizmem a antynaturalizmem. Rozdział zawiera omówienie różnych typów naturalizmu i antynaturalizmu. Filozof odsłania przed czytelnikiem wady i zalety prezentowanych podejść. Przekonuje, że strategie te mogą być potraktowane jako komplementarne, jeśli tylko zrezygnuje się $\mathrm{z}$ radykalizmu, który nierzadko towarzyszy wygłaszanym poglądom na rzecz naturalizmu czy antynaturalizmu.

Recenzowana pozycja to bardzo dobre wprowadzenie do metodologii nauk społecznych dla tzw. nowicjuszy, którzy w tym obszarze nauki stawiają pierwsze kroki. Profesor Trzęsicki dobrze odczytał potrzeby tych, dla których solidny warsztat metodologiczny jest konieczny w rzetelnym uprawianiu nauki. Rzeczywiście książka ta daje czytelnikowi solidne wprowadzenie teoretyczne, jak również dostarcza szereg praktycznych wskazówek, jak rzetelnie prowadzić badania naukowe.

Walorem publikacji jest przejrzysty układ zagadnień, klarowne podziały, jasne typologie. To, że materiał został uporządkowany w sposób logiczny, jest znów wielką pomocą dla badacza społecznego, który zaczyna dopiero zdobywać szlify metodologiczne. Precyzyjna kompozycja tekstu sprawia, że tak naprawdę książkę można zacząć czytać od dowolnego rozdziału, zgodnie z zainteresowaniami badawczymi. Oczywiście dopiero solidne studium całości pozwala nam uzyskać coś w rodzaju propedeutycznego rozeznania w problemach metodologii badań społecznych.

Książka przede wszystkim uczy myśleć, i to jest jej podstawowe przesłanie. Profesor Trzęsicki pokazuje, że metodologia nie polega na biernym przyswajaniu informacji o czynnościach badawczych, stosowanych 
metodach czy ocenach rezultatów badawczych. To właśnie metodologia ma uczyć krytycznego myślenia, w którym liczą się argumenty, a nie emocje czy przywiązania do autorytetów. Autor, oprócz tego, że dokonuje precyzyjnych rekonstrukcji różnych koncepcji i podejść do metodologii badań społecznych, zachęca czytelnika do samodzielnego wejścia na tory krytycznego myślenia. Może niektórych zaskakiwać, że na etapie propedeutycznego wprowadzenia autor zachęca do krytyki zapoznawanych stanowisk. Wydaje się jednak, że jeśli chcemy kształtować umiejętności i kompetencje krytycznego myślenia, musimy zaczynać jak najwcześniej, właśnie na etapie przyswajania rudymentów, tak aby $\mathrm{w}$ adeptach nie dopuścić do zakorzenienia się postaw fundamentalistycznych. Filozof pokazuje racje za i przeciw określonym koncepcjom metodologii. Wszak zwrócenie uwagi na rolę argumentacji za określonymi stanowiskami ma walor nie tylko teoretyczny, lecz także dydaktyczny. Uczy adepta badań społecznych krytycznego myślenia, dystansu wobec analizowanych opcji, a przede wszystkim ćwiczy w kompetencji do sprawnego formułowania logicznie spójnych argumentów. Formułowaniu argumentacji za lub/i przeciw towarzyszą autorskie próby znalezienia stanowiska pośredniego. Profesor Trzęsicki przestrzega, aby na początku swojej drogi badawczej młody adept nie wpadał w pułapkę skrajności, która w ostateczności zawsze jest drogą bez wyjścia. Uczy natomiast, że rzetelna analiza racji za i przeciw może prowadzić do sformułowania wypośrodkowanego stanowiska, które docenia wady i zalety krytykowanych stanowisk, zaś umiejętność myślenia syntetycznego prowadzi do stworzenia opcji środka, która integruje to, co w zwalczających się czasem opcjach jest najbardziej wartościowe, co może prowadzić do formułowania bardziej przekonujących wyjaśnień zjawisk społecznych.

Monografia została napisana prostym językiem. To duży walor tego podręcznika. Widać, że został on stworzony przede wszystkim z myślą o studentach, którym studiowanie metodologii nie przychodzi łatwo, a taką właśnie barierą utrudniającą przebicie się przez mur problemów, zagadnień jest przeważnie język, za pomocą, którego zostały sformułowane. Autor, który jest wytrawnym znawcą logiki i retoryki, w klarowny 
sposób zaprezentował czytelnikom szereg bardzo skomplikowanych zagadnień związanych z metodologią nauk społecznych. W sposób szczególny dla nowicjusza, który dopiero co stawia pierwsze kroki w obszarze badań społecznych, który nie zdołał jeszcze opanować teoretycznie zawansowanego języka, książka prof. Kazimierza Trzęsickiego jest niczym światło w mroku, które punktowo i precyzyjnie, ale jednocześnie nie oślepiając, umożliwia widzenie skomplikowanych zagadnień.

Wprowadzenie do metodologii nauk społecznych to obowiązkowa lektura dla wszystkich nowicjuszy, którzy stawiają pierwsze kroki na niełatwym terenie badań społecznych. Bezwzględnie sprawdzi się jako akademicki podręcznik przeznaczony dla studentów nauk społecznych, ale i humanistycznych. Recenzowana pozycja dostarcza bowiem podstawowego instrumentarium pojęciowego, którego przyswojenie jest warunkiem koniecznym przejścia na bardziej zaawansowane etapy studiowania metodologii nauk społecznych. Można powiedzieć, że książka jest ową wittgensteinowską drabiną, na którą każdy, kto poważnie traktuje uprawianie nauk, musi wejść, aby później móc ją z czystym sumieniem „odrzucić” i rozpocząć nową wspinaczkę, prowadzącą do zdobycia wyższego poziomu kompetencji metodologicznych. Również od strony redakcyjnej książka zachęca do przeczytania. Wprawdzie gdzieniegdzie można wyłapać literówki i drobne potknięcia stylistyczne, ale generalnie rzecz ujmując, publikacja została dobrze zredagowana. Zachętą do książki, co raz jeszcze chciałabym podkreślić, jest klarowne uporządkowanie materiału oraz język za pomocą, którego został on przedstawiony. 